\title{
Penguatan Nilai-Nilai Pendidikan Karakter Melalui Game Edukasi Icando di Sekolah Dasar
}

\author{
Syaiful Bahri ${ }^{1}$, Agus Wahdian ${ }^{2}$
}

syaifulbahri@stkippgrisumenep.ac.id, STKIP PGRI Sumenep ${ }^{1}$

aguswahdian@stkippgrisumenep.ac.id, STKIP PGRI Sumenep ${ }^{2}$

STKIP PGRI Sumenep ${ }^{1}$

STKIP PGRI Sumenep ${ }^{2}$

\begin{abstract}
Abstrak: Tujuan penelitian ini adalah penguatan nilai-nilai pendidikan karakter anak di sekolah Dasar Negeri Batubelah Timur I dan Sekolah Dasar Negeri Bates I melalui aplikasi game edukasi Icando. Metode penelitian yang digunakan dalam penelitian ini adalah metode penelitian kualitatif dengan pendekatan diskriptif. Teknik pengumpulan data yang digunakan adalah observasi dan wawancara. Hasil penelitian ini menunjukkan bahwa aplikasi game edukasi Icando dapat berkontribusi dalam penguatan nilai-nilai pendidikan karakter diantaranya nilai karakter percaya diri, hormat dan santun kepada orang tua, tanggung jawab, rasa ingin tahu, menghargi prestasi, peduli sosial, peduli lingkungan, kreatif, dan pantang menyerah.
\end{abstract}

Kata kunci: Penguatan Nilai-Nilai Pendidikan karakter, Game Edukasi, Icando

\section{Strengthening Character Education Values through Icando Educational Games in Elementary School}

Abstract: The purpose of this study is to strengthen the values of character education for children in Batubelah Timur I State Elementary School and Bates I State Elementary School through the Icando educational game application. The research method used in this research is a qualitative research method with a descriptive approach. The data collection techniques used were observation and interviews. The results of this study indicate that Icando educational game applications can contribute to strengthening the values of character education, including character values of self-confidence, respect and courtesy to parents, responsibility, curiosity, respect for achievement, social care, environmental care, creative, and abstinence. give up.

Keywords: Strengthening the values of character education, Game Education, Icando

\section{PENDAHULUAN}

Era Revolusi Industri 4.0 sudah menyeluruh di penjuru dunia termasuk di indonesia, dimana era ini menjadikan era yang serba mudah berkat teknologi yang dapat memudahkan tugas-tugas manusia termasuk dalam segi pendidikan yang memudahkan 
Kukuh, Rian, Bagus. Empat Kata Judul Dari Depan...

akses ruang pembelajaran menjadi semakin mudah dengan adanya serba-serbi teknologi. Era revolusi Industri 4.0 dapat juga membantu sistem pembelajaran baik di tingkat sekolah dan perguruan tinggi, dengan adanya teknologi ini mampu membantu sistem-sistem yang ada di sekolah misalnya dalam mengimput data hasil belajar siswa dan lain sebagainya. Dengan perkembangan teknologi dari hari kehari semakin canggih juga bisa berdampak fatal pada perkembangan karakter pada siswa sekolah dasar.

Perkembangan teknologi di era sekarang yang serba canggih, perlu dimanfaatkan untuk memberikan edukasi yang membangun perkembangan anak di usia sekolah dasar, seperti halnya untuk membangun karakter anak menjadi lebih baik lagi. Mengacu pada pertumbuhan anak usia dini ke remaja bahkan sampai dewasa pada zaman sekarang, dimana maraknya remaja-remaja di zaman sekarang yang tingkat kenakalannya bisa dikatakan terlalu over, hal ini dibuktikan dengan maraknya anak remaja yang ketergantungan terhadap narkotika dari setiap tahunnya meningkat, tauran remaja dan kekerasan antar remaja juga tidak bisa terhidarkan lagi. Oleh sebab itu perlu adanya sebuah pembelajaran yang itu menyangkut langsung dengan pertumbuhan karakter anak.

Masalah krisis moral dan karakter adalah perbincangan yang serius dan terus menerus. Bangsa Indonesia krisis moral dan karakterv yang luar biasa. Beberapa tahun bahkan bulan terakhir gencar disuguhkan bagaimana hancurnya moral anak-anak, mulai dari pelecehan seksual, pencabulan di mana-mana, padahal nasib bangsa ini bergantung pada mereka (Ridwan, 2016:95)

Pendidikan karakter pada pembelajaran di usia sekolah dasar merupakan fondasi awal untuk membentuk karakter anak atau siswa agar dapat memilah hal yang baik dan buruk ketika melakukan sesuatu. Maka dengan lebih memfokuskan pada sistem pembelajaran siswa terhadap pendidikan karakter untuk meminalisir kenakalan anak ketika sudah meranjak usia remaja, apalagi dengan setiap tahun-tahunnya perkembangan teknologi akan semakin canggih.

Karakter dapat dimaknai sebagai keadaan asli yang ada dalam diri individu seseorang yang membedakan antara dirinya dengan orang lain. Karakter merupakan perilaku manusia yang berhubungan dengan Tuhan Yang Maha Esa, diri sendiri, sesama manusia, lingkungan, dan kebangsaan yang terwujud dalam pikiran, sikap, perasaan, perkataan, dan perbuatan berdasarkan norma-norma agama, hukum, tata krama, budaya, 
Kukuh, Rian, Bagus. Empat Kata Judul Dari Depan... dan adat istiadat (Gunawan, 2012: 3). Sedangkan Tilaar (Wahyu, 2011) mengemukakan istilah karakter (character) atau dalam bahasa Indonesia diterjemahkan dengan watak adalah sifat-sifat hakiki seseorang atau suatu kelompok atau bangsa yang sangat menonjol sehingga dapat dikenali dalam berbagai situasi atau merupakan trade mark seseorang.

Tahapan Pembentukan karakter menurut Astuti (2020:66) (1) Adanya nilai yang erap seseorang dari berbagai sumber, kemudian (2) nilai tersebut membentuk pola fikir seorang yang secara keseluruhan keluar dalam bentuk rumusan visi, (3) visi turun ke wilayah hati membentuk suasana jiwa yang secara keseluruhan membentuk mentalitas, dan kemudian(4) mentalitas mengalir memasuki wilayah fisik dan melahirkan tindakan yang secarakeseluruhan disebut sikap.

Proses pembelajaran merupakan kegiatan terencana untuk mencapai hasil yang maksimal, sehingga mampu mengantarkan kepada tujuan pembelajaran yang diinginkan, oleh karena membutuhkan proses pembelajaran yang inovatif guna mencapai itu semua termasuk memberikan sebuah pembelajaran yang berbasis pedidikan karakter. Sebagaimana diketahui bahwa anak atau siswa yang berada di usia sekolah dasar merupakan suatu periode awal yang paling penting dan mendasar sepanjang rentang pertumbuhan serta perkembangan kehidupannya. Salah satu periode yang menjadi penciri masa anak ketika masih menjadi siswa yaitu Golden Age atau periode keemasan. Banyak konsep dan fakta yang telah ditemukan memberikan penjelasan bahwa periode keemasan adalah pada masa anak-anak, dimana pada saat masih menjadi anak-anak potensi yang dimiliki oleh anak akan berkembang paling cepat. membangun pendidikan karakter anak yang masih berusia tujuh sampai dua belas tahun ini akan mampu memberikan dampak positif yang signifikan berupa nilai-nilai kejujuran, tanggung jawab, saling menghargai dan masih banyak lagi, dimana nantinya ketergantungan anak pada teknologi tidak akan lagi over.

Game Edukasi merupakan salah satu jenis media pembelajaran yang dirancang dalam konsep permaianan yang bertujuan untuk memberikan pengetahuan, ketarampilan, ketangkasan dan ditampilkan dalam bentuk yang unik dan menarik.

Media Game Edukasi merupakan media pembelajaran yang disusun dalam bentuk permaianan yang dirancang untuk memberikan pengalaman pendidikan atau 
Kukuh, Rian, Bagus. Empat Kata Judul Dari Depan... pengalaman belajar kepada para pemainnya yang disajikan secara menyenangkan dan merupakan cara yang bersifat mendidik (Abdullah, 2015:298)

Aplikasi Game Icando adalah aplikasi game pendidikan anak yang dikelola oleh PT ICD Karya Indonesia. Icando merupakan game kekinian yang di konsep menarik untuk proses pembelajaran di sekolah, terlebih pada masa pandemi covid-19. Selain itu, pada setiap konten terdapat kuis sebagai bentuk refleksi. Icando memiliki banyak konten yang sangat bermanfaat untuk anak sekolah dasar. Konten-konten yang terdapat dalam Icando juga menyesuaikan dengan perkembangan kurikulum 2013. Pembelajaran yang dilakakukan saat pandemi Covid-19 Guru menggukan aplikasi game edukasi Icando sebagai media untuk membangun nilai-nilai pendidikan karakter pada anak usia sekolah dasar. Proses pembelajaran yang dikonsep menarik dengan berbagai tema dan sub tema yang di spesifikasi menjadi konten. Icando memiliki konten pembelajaran yang tidak membosankan, setiap konten terdapat video yang banyak mengandung nilai-nilai pendidikan karakter dan pengetahuan.

Tujuan Penelitian ini adalah sebagai sarana dalam penguatan dan penanaman nilai-nilai pendidikan di sekolah dasar ditengah pandemi covid-19 yang di konsep dalam bentuk pembelajaran dengan menggunakan game edukasi Icando. Berdasarkan uraian diatas maka peneliti menyusun penelitian dengan judul "Penguatan Nilai-Nilai

\section{Pendidikan Karakter Melalui Game Edukasi Icando Sekolah Dasar” METODE}

Penelitian ini dilakukan di SDN Batu Belah Timur I dan SDN Bates I kecamatan Dasuk Kabupaten Sumenep. Jenis penelitian ini adalah penelitian kualitaitf deskriptif, yaitu data yang dikumpulkan berbentuk kata-kata, gambar, bukan angka-angka. Menurut Bogdan dan Taylor, sebagaimana yang dikutip oleh Lexy J. Moleong, penelitian kualitatif adalah prosedur penelitian yang menghasilkan data deskriptif berupa kata-kata tertulis atau lisan dari orang-orang dan perilaku yang diamati. (Lexy. J. Moleong, 2009; 9).

A. Teknik Pengumpulan Data

1. Observasi, digunakan untuk mengetahui kondisi awal proses penguatan nilai-nilai pendidikan karakter yang dilakukan oleh guru kelas awal di SDN Bates I dan SDN Batubelah Timur I; 
Kukuh, Rian, Bagus. Empat Kata Judul Dari Depan...

2. Wawancara, digunakan untuk mengumpulkan data primer dalam penelitian. Wawancara ini dilakukan dengan guru kelas awal di SDN Bates I dan SDN Batubelah Timur I;.

\section{B. Teknik Analisis Data}

Teknik analisis data yang digunakan dalam penelitian ini dimulai dari seluruh data yang terkumpul dari pengamatan, catatan lapangan, wawancara, dan dokumentasi di interpretasikan secara kualitatif untuk mengetahui keabsahan data dalam penarikan kesimpulan. Sugiyono (2010; 337), aktivitas dalam analisis data kualitatif dilakukan secara interaktif dan berlangsung secara terus menerus sampai tuntas. Hal ini dikarenakan proses analisis data kualitatif berlangsung selama dan pasca pengumpulan data.

Menurut Miles dan Huberman, kegiatan analisis terdiri dari tiga alur kegiatan yang terjadi secara bersamaan, yaitu reduksi data, penyajian data, dan penarikan kesimpulan/verivikasi. Terjadi secara bersamaan berarti reduksi data, penyajian data, dan penarikan kesimpulan/verivikasi sebagai sesuatu yang saling jalin menjalin merupakan proses siklus dan interaksi pada saat sebelum, selama, dan sesudah pengumpulan data dalam bentuk sejajar yang membangun wawasan umum yang disebut “analisis" (Ulber Silalahi, 2009: 339).

Berdasarkan uraian diatas maka teknik analisis data pada penelitian ini adalah sebagai berikut :

1. Reduksi data;

2. Penyajian data;

3. Triangulasi data;

4. Penarikan kesimpulan

\section{HASIL}

Berdasarkan hasil observasi dan wawancara kepada guru kelas awal di Dasar Negeri Batu belah Timur I dan SDN Bates I kecamatan Dasuk, maka diperoleh data terkait penguatan nilai-nilai pendidikan karakter anak usia Sekolah Dasar Negeri Batu belah Timur I dan SDN Bates I kecamatan Dasuk Kabupaten Sumenep pada saat pandemi covid-19 bersadarkan hasil analisis dan implementasi nilai-nilai pendidikan 
Kukuh, Rian, Bagus. Empat Kata Judul Dari Depan...

karakter yang terdapat dalam setiap konten yang terkonsep pada tema diriku, sub tema

(1) aku dan teman baru; (2) Tubuhku pada game edukasi Icando sebagaimana berikut :

Tabel. 1

Nilai-Nilai Pendidikan Karakter Game Edukasi Icando

Tema Diriku Sub Tema Aku dan Teman Baru

\begin{tabular}{|c|c|c|c|}
\hline No & Konten & $\begin{array}{c}\text { Nilai } \\
\text { Pendidikan } \\
\text { Karakter }\end{array}$ & Ilustrasi \\
\hline 1 & Profil diri & Percaya Diri & $\begin{array}{l}\text { Siswa diminta untuk melakukan } \\
\text { foto selfi serta menuliskan } \\
\text { identitas pada layar handphone }\end{array}$ \\
\hline 2 & Senam & Kerja sama & $\begin{array}{l}\text { Alina bermain bersama teman- } \\
\text { temannya di taman }\end{array}$ \\
\hline 3 & Menyusun buku & $\begin{array}{l}\text { Hormat dan } \\
\text { santun kepada } \\
\text { orang tua, } \\
\text { tanggung jawab }\end{array}$ & $\begin{array}{l}\text { Ketika ucok mengajak teman- } \\
\text { temannya bertemu ibunya di } \\
\text { perpustakaan yang sedang } \\
\text { mengajar membaca, dengan } \\
\text { santun Alina bersalaman dengan } \\
\text { mencium tangan ibu ucok dengan } \\
\text { memperkenalkan diri dan diikuti } \\
\text { oleh semua teman-teman Alina, } \\
\text { diantaranya Noni, Arman, Joko } \\
\text { dan terakhir Eben. Nilai karakter } \\
\text { tanggung jawab dan amanah } \\
\text { adalah ibu joko meminta bantuan } \\
\text { kepada Alin dan teman-temannya } \\
\text { untuk menyusun buku di rak } \\
\text { sesuai dengan lambang bilangan, } \\
\text { mereka melakukan itu dengan } \\
\text { baik }\end{array}$ \\
\hline 4 & Menebak judul buku & $\begin{array}{c}\text { Rasa Ingin } \\
\text { Tahu }\end{array}$ & $\begin{array}{l}\text { Noni bertanya kepada joko dan } \\
\text { meminta untuk menceritakan } \\
\text { kembali, lalu oleh ibu ucok } \\
\text { bertkata, jika kalian ingin } \\
\text { berpetualang dengan isi buku ini } \\
\text { kalian harus bisa membaca. Ibu } \\
\text { ucok mengajak mereka untuk } \\
\text { belajar mengenal huruf dengan } \\
\text { cara bernyanyi dari huruf A-Z. }\end{array}$ \\
\hline 5 & Menghitung 10 & $\begin{array}{l}\text { Menghargi } \\
\text { prestasi }\end{array}$ & $\begin{array}{l}\text { Ibu Ucok sangat apresiatif } \\
\text { terhadapa kehadiran Alina dan } \\
\text { kawan-kawan di perpustakaan. }\end{array}$ \\
\hline 6 & Menghitung jumlah benda & Peduli sosial & $\begin{array}{l}\text { Alina membantu Ibu untuk } \\
\text { meletakkan peralatan dapur pada }\end{array}$ \\
\hline
\end{tabular}


Kukuh, Rian, Bagus. Empat Kata Judul Dari Depan...

\begin{tabular}{|c|c|c|l|}
\hline & & & $\begin{array}{l}\text { rak. Menghitung jumlah perkakas } \\
\text { dapur dan dimasukkan kedalam } \\
\text { rak menjadi kuis menarik pada } \\
\text { konten ini. }\end{array}$ \\
\hline 7 & Menyebutkan nama teman & Peduli Sosial & $\begin{array}{l}\text { Alina Ucok, Joko, Noni dan } \\
\text { Eben berlari, tapi dalam } \\
\text { perjalanan Joko kelelehan, lalu } \\
\text { Ucok datang untuk memberikan } \\
\text { semangat dan membantu Joko. }\end{array}$ \\
\hline 8 & Keluarga Istimewaku & $\begin{array}{l}\text { Karakter peduli } \\
\text { lingkungan dan } \\
\text { kreatif }\end{array}$ & $\begin{array}{l}\text { "Pak Cahya setiap pagi berjalan } \\
\text { mengelilingi kampung, pak } \\
\text { Cahya mengumpulkan benda } \\
\text { tidak terpakai seperti kaleng, } \\
\text { botol, potongan kayu atau ranting. } \\
\text { Benda-benda bekas tersebut } \\
\text { dibawa Pak Cahya ke bengkel } \\
\text { kecil disamping rumah. Benda } \\
\text { benda tersebut kemudian Pak } \\
\text { cahya ubah. Terkadang dia ubah } \\
\text { menjadi rak bambu, talenan, dan } \\
\text { pot bunga" }\end{array}$ \\
\hline 9 & Menghitung perkakas & Peduli sosial & $\begin{array}{l}\text { Alina membantu ayahnya untuk } \\
\text { merapikan perkaka }\end{array}$ \\
\hline
\end{tabular}

Tabel 2. Nilai-Nilai Pendidikan Karakter Game Edukasi Icando Tema Diriku Sub Tema Aku Tubuhku

\begin{tabular}{|c|c|c|l|}
\hline No & Konten & $\begin{array}{c}\text { Nilai } \\
\text { Pendidikan } \\
\text { Karakter }\end{array}$ & \multicolumn{1}{|c|}{ Ilustrasi } \\
\hline 1 & Membuka koper & $\begin{array}{c}\text { Hormat dan } \\
\text { santun }\end{array}$ & $\begin{array}{l}\text { Pada tanyangan ini Ibu Alina } \\
\text { bersikap santun kepada setiap } \\
\text { orang dengan bertegur sapa, dan } \\
\text { bersikap santun kepada penjual } \\
\text { gelang dengan mengucapkan kata } \\
\text { maaf ketika tidak membeli gelang }\end{array}$ \\
\hline 2 & Bumbu dapur & $\begin{array}{l}\text { Pantang } \\
\text { menyerah }\end{array}$ & $\begin{array}{l}\text { Game pertahanan diri dari } \\
\text { serangan kelabang, meskipun } \\
\text { kelabang menyerang Arya dengan } \\
\text { jumlah yang banyak, siswa } \\
\text { melindungi Arya dari serangan } \\
\text { kelabang. }\end{array}$ \\
\hline 3 & $\begin{array}{c}\text { Bubu dan Ikan Tangkapan } \\
\text { Ayah }\end{array}$ & $\begin{array}{l}\text { Percaya diri, } \\
\text { Peduli Sosial, } \\
\text { Pantang } \\
\text { menyerah dan } \\
\text { menghargai }\end{array}$ & $\begin{array}{l}\text { para pembeli mulai berdatangan, } \\
\text { Bubu menawarkan ikan dengan } \\
\text { gencar (Percaya diri) Bubu } \\
\text { mengobati kaki pria yang } \\
\text { bercerita pengalaman saat }\end{array}$ \\
\hline
\end{tabular}


Kukuh, Rian, Bagus. Empat Kata Judul Dari Depan...

\begin{tabular}{|c|c|c|c|}
\hline & & prestasi & $\begin{array}{l}\text { berlayar dan paman mendorong } \\
\text { pintu dan memarahi pria jahat } \\
\text { untuk menolong bubu, selain itu } \\
\text { paman mengantarkan bubu } \\
\text { pulang (Peduli Sosial); Bubu } \\
\text { melakukan perlawanan dengan } \\
\text { cara berteriak dan mendorong } \\
\text { pria jahat (Pantang menyerah); } \\
\text { Ibu dan Bubu mengucapkan } \\
\text { terima kasih kepada paman } \\
\text { (Menghargi prestasi). }\end{array}$ \\
\hline 4 & Melindungi diri & $\begin{array}{c}\text { Kerjasama, } \\
\text { Bersahabat, dan } \\
\text { Peduli sosial, } \\
\text { Pantang } \\
\text { menyerah }\end{array}$ & $\begin{array}{l}\text { alina bermain bersama teman- } \\
\text { temannya (Kerja sama); } \\
\text { Bersosialisasi dan mengajak } \\
\text { temannya bermain bersama (kerja } \\
\text { sama) } \\
\text { Ibu mengobati luka alina karena } \\
\text { terpeleset saat berlari melindungi } \\
\text { diri dari lelaki penjaga toko yang } \\
\text { berusaha memegang tubuh alina } \\
\text { (peduli sosial); } \\
\text { pada adegan ketika melawan } \\
\text { orang asing, maka langkah } \\
\text { pertaman harus berteriak dengan } \\
\text { sangat kecang, setalah itu lari } \\
\text { dengan cepat sampai bertemu } \\
\text { dengan orang tua } \\
\text { menceritakan kepada orang tua } \\
\text { (pantang menyerah). }\end{array}$ \\
\hline 5 & $\begin{array}{l}\text { Anggota tubuh dan } \\
\text { wajahku }\end{array}$ & Kreatif & $\begin{array}{l}\text { Game memasangkang bagian } \\
\text { organ tubuh yang dibuat terpisah } \\
\text { pada gambar sesuai dengan } \\
\text { tempatnya. }\end{array}$ \\
\hline
\end{tabular}

\section{PEMBAHASAN}

Analisis di lapangan, Game aplikasi Icando memberikan pengalaman baru bagi siswa di sekolah dasar, konsep belajar yang menarik denga sistem belajar sambil bermain sangat mendunkung ketercapaian tujuan pembelajaran yaitu game dengan konsep petualangan dan penuh dengan nilai-nilai karakter (game edukasi Icando)

Tujuan program Penguatan Pendidikan Karakter adalah menanamkan nilai-nilai pembentukan karakter bangsa ke peserta didik secara masif dan efektif melalui lembaga pendidikan dengan prioritas nilai-nilai tertentu yang akan menjadi fokus pembelajaran, pemahaman, pengertian, dan praktik, sehingga pendidikan karakter sungguh dapat 
Kukuh, Rian, Bagus. Empat Kata Judul Dari Depan... mengubah perilaku, cara berpikir, dan cara bertindak seluruh bangsa Indonesia menjadi lebih baik dan berintegritas (Khotimah, 2019:28).

Petualangan pada game edukasi Icando tersebut dimulai dari memberi salam, mencuci tangan, menggosok gigi sampai pada materi belajar kelas 1. Disini tentu sudah menunjukkan nilai karakter yang sangat jelas kepada peserta didik di awal game, Nilai karakter yang dimaksud seperti halnya Religius, Mandiri, dan peduli lingkungan. Kegiatan mencuci tangan misalnya yang secara gamblang memberikan nilai religius dan mandiri kepada peserta didik dan kegiatan ilustrasi menggosok gigi yang memiliki nilai karakter berupa peduli lingkungan. Pada setiap konten di tema diriku, guru memandu siswa untuk menyimak video dan mengikuti kuis yang ada.

Sebagaimana tertera pada rumusan dan tujuan penelitian di awal, penelitian ini terfokus pada implementasi penguatan nilai-nilai pendidikan karakter malalui game Icando di kelas awal pada masa pandemi covid-19 dilaksanakan pada dua sub tema yaitu "aku dan teman baru" serta "tubuhku" yang merupakan bagian dari tema "diriku".

\section{A. Aku dan Teman Baru}

Tema diriku sub tema aku dan teman baru merupakan sub tema awal dalam video tersebut dimana di dalamnya memiliki beberapa kegiatan yang sangat bersentuhan langsung dengan aktifitas siswa dalam keseharian siswa. Sub tema aku dan teman baru sangatah ccocok untuk diletakkan pada awal game dimana siswa dilatih untuk mengenal diri sendiri sebeum mereka harus berlajar tentang materi di luar dirinya.

Ada beberapa konten yang ada pada sub-tema "Aku dan Teman Baru" yang dikemas dengan dengan menarik dan penuh kreatifitas. konten-konten yang dimaksud adalah profil diri, senam, menyusun buku 1, menyusun buku 2, menebak judul buku, menghitung 10, menghitung jumlah benda, menebak nama teman 1, menebak nama teman 2, aku dan keluarga istimewaku, menghitung perkakas, buku harian dan terakhir konten mari berhitung.

Konten tersebut disusun dengan menarik dan kreatif sehingga tidak membosankan, begitu pula dengan nilai karakter yang coba ditanamkan dalam game tersebut pada setiap konten yang juga sangat beragam. Dari 18 nilai karakter yang dikembangkan dalam kurikulum 2013, ada beberapa nilai karakter yang coba diilustrasikan dalam game tersebut dengan sistem terpisah sesuai konten. Hal ini dimaksudkan untuk maksimalisasi implementasi nilai-nilai karakter yang sangat 
Kukuh, Rian, Bagus. Empat Kata Judul Dari Depan...

beragam tersebut. Adapun nilai karakter pada masing-masing konten adalah sebagai berikut :

\section{Konten profil diri}

Penguatan nilai karakter kepada siswa yang tertera dalam konten ini adalah percaya diri dan Mandiri. Siswa dengan adanya konten ini diharapkan dapat percaya diri untuk melakukan sesuatu yang dituntut dengan perintah berupa mengambil foto diri dan menulis identitas pribadi. Hal ini selaras dengan statemen dari Jin dan Cortazzi (dalam Gyanprakash dkk, 2013) siswa yang memiliki keyakinan akan kemampuannya dan motivasi dalam proses belajarnya dapat memunculkan kemandirian belajar dalam diri siswa.

Game tersebut berisikan ilustrasi dimana siswa diminta untuk melakukan foto serta menuliskan identitas pada layar handphone. Guru mengajak dan memandu siswa melakukan foto dan menuliskan identitas pada game Icando tersebut secara tidak langsung mereka sudah melatih mandiri yang juga bagian nilai karakter itu sendiri.

2. Konten senam

Berbeda dengan konten pertama yang berupa permintaan melakukan tindakan, konten "Senam" ini dikemas dengan tayangan video senam yang dilakukan oleh alina dan kawan-kawan. Tayangan senam tersebut mengajarkan betapa pentingnya kebersamaan, bahwa manusia sebagai mahluk sosial yang harus bekerjasama dengan orang lain. Apriono (2011) menjelaskan kemampuan kerjasama dapat diartikan sebagai kemampuan yang dilakukan oleh beberapa siswa untuk saling membantu satu sama lain sehingga tampak kebersamaan dan kekompakan untuk mencapai tujuan bersama. Kebersamaan adalah nilai karakter yang coba diimplementasikan dalam konten "senam" tersebut. Dalam penguatan nilai ini guru menggambarkan dan menjelaskan kembali ilustrasi yang ada dalam konten tersebut serta mengajak siswa untuk menerapkan dalam kehidupan sehari-hari mereka.

3. Konten menyusun buku

Nilai pendidikan karakter yang diperoleh oleh siswa pada konten ini adalah hormat dan santun kepada orang tua, tanggung jawab dan amanah. konsep pada konten ketiga ini sama halnya dengan konten sebelumnya yaitu dengan bentuk video. Sopan santun menurut Antoro (2010:3) sebagai perilaku individu yang menjunjung tinggi nilai-nilai menghormati, menghargai, tidak sombong dan berakhlak mulia Ilustrasinya 
Kukuh, Rian, Bagus. Empat Kata Judul Dari Depan...

sesuai hasil analisis pada game tersebut, Ketika ucok mengajak teman-temannya bertemu ibunya di perpustakaan yang sedang mengajar membaca, dengan santun Alina bersalaman dengan mencium tangan ibu ucok sembari memperkenalkan diri dan diikuti oleh semua teman-teman Alina, diantaranya Noni, Arman, Joko dan terakhir Eben. Pola penguatan yang dilakukan oleh guru pada konten ini menggunakan polistrategi yakni dengan cara melakukan integrasi nilai-nilai pendidikan karakter hormat, santun dan tanggung jawab serta amanah.

Nilai karakter tanggung jawab dan amanah tampak dalam ilustrasi ketika ibu joko meminta bantuan kepada Alin dan teman-temannya untuk menyusun buku di rak sesuai dengan lambang bilangan, mereka melakukan itu dengan baik. Kegiatan menyusun buku yang dilakukan oleh siswa tersebut sesuai perintah guru adalah bentuk tanggung jawab dan amanah. Akhir dari konten ini adalah kuis mencocokkan lambang bilangan. Proses penguatan nilai-nilai pendidikan karakter dalam konten ini dilakukan oleh guru ketika siswa selesai menonton video pada konten ini dengan cara melakukan review dan memberikan analogi serta contoh-contoh dalam kehidupan nyata.

4. Menebak judul buku

Pendidikan karakter berupa rasa Ingin tahu dan gemar membaca merupakan nilai yang coba ditanamkan lewat game pada konten "Menebak judul buku" ini. Analisis pada game, Noni bertanya kepada joko dan meminta untuk menceritakan kembali, lalu ibu ucok berkata, jika kalian ingin berpetualang dengan isi buku ini kalian harus bisa membaca. Ibu ucok mengajak mereka untuk belajar mengenal huruf dengan cara bernyanyi dari huruf A-Z. Konten ini diakhiri dengan kuis menyusun huruf yang sudah tersedia dalam kotak.

Nilai pendidikan karakter Ingin tahu sangat penting dimiliki oleh siswa sekolah dasar, guru mencoba untuk menguatkan nilai sebagai dasar pemngembangan intelektual siswa. Rasa ingin tahu adalah cara berpikir, sikap dan perilaku yang mencerminkan penasaran dan keingintahuan terhadap segala hal yang dilihat, didengar, dan dipelajari secara lebih mendalam (Kementerian Pendidikan Nasional, 2010:10). Penguatan nilai ingin tahu juga akan berdampak terhadap minat baca siswa di sekolah dasar. Hal ini juga di ilustrsikan dalam konten ini berupa kegiatan ibu ucok yang mengajak joko dan noni untuk mengeja huruf serta pemberian pemahaman akan pentingnya membaca serta permintaan noni kepada joko untuk menceritakan kembali tentang isi buku merupakan 
Kukuh, Rian, Bagus. Empat Kata Judul Dari Depan...

kegiatan yang mengandung implementasi nilai karakter berupa gemar membaca dan rasa ingin tahu.

5. Konten menghitung 10

Nilai karakter yang ditanamkan dalam konten ini adalah menghargai prestasi dimana siswa pada akhirnya diharapkan dapat menghargai segala sesuatu yang terjadi di kehdiupan ini; termasuk perihal prestasi. Nilai karakter ini diimplementasikan dalam game tersebut berupa ilustrasi kegiatan Ibu Ucok memberikan cindera mata atau hadiah kepada siswa. Hal ini dilakukan karena Ibu Ucok sangat apresiatif terhadapa kehadiran Alina dan kawan-kawan di perpustakaan. Mengahragai prestasi merupakan nilai karakter pokok yang harus dimiliki oleh siswa di sekolah dasar. Pentingnya penguatan karakter menghargai prestasi adalah untuk dapat menghargai karya orang lain, tidak gampang membully apalagi mencaci tindakan dan proses orang lain, dan yang terpenting siswa dapat mengahragai karya orang lain dengan cara tidak melakukan plagiasi karya cipta. Hal ini selaras dengan proses character development yang disampaikan oleh Khoiri (2018:103) But, in fact, the character also does not develop by itself. In each individual, character development is influenced by internal factors and external factors.

Pada konten ini pula anak-anak diminta menghitung jumlah pensil dan alat tulis yang berikan oleh Ibu Ucok. Kuis menghitung alat tulis dan menulikan jumlahnya pada kolom. Rasa ingin tahu juga tampak dalam konten ini sebagai sebuah nilai tersendiri.

6. Konten menghitung jumlah benda I

Selain individualis seperti halnya mandiri, tanggung jawab dan rasa ingin tahu, game ini juga mengimplementasikan nilai karakter yang bersifat kemasyarakat yaitu peduli sosial sebagaimana tertera jelas dalam konten ke enam ini. Kegiatan pada game tersebut, Alina membantu Ibunya untuk meletakkan peralatan dapur pada rak. Menghitung jumlah perkakas dapur dan dimasukkan kedalam rak menjadi kuis menarik pada konten ini. Jika analisis dalam bentuk tindakan pada game tersebut jelas Alina melakukan kegiatan peduli sosial berupa membantu ibunya. Zuchdi (2011: 170) menjelaskan bahwa, peduli sosial merupakan sikap dan tindakan yang selalu ingin memberi bantuan kepada masyarakat. Guru mengajak siswa untuk segera merealisasikan karakter peduli social dalam kehidupan sehari-hari mereka.

7. Konten menyebutkan nama teman 
Kukuh, Rian, Bagus. Empat Kata Judul Dari Depan...

Pada konten ini, game berisi ilustrasi cerita yang pada akhirnya siswa diminta untuk mengingat nama-nama tokoh dalam cerita tersebut. Nilai karakter yang terimplementasikan dalam konten ini adalah peduli sosial dan kerja keras; yang disampaikan secara tersurat dan tersirat.

"Mereka berlari, tapi dalam perjalanan Joko kelelehan, lalu Ucok datang untuk memberikan semangat dan membantu Joko", inilah kutipan cerita pada ilustrasi video pada game tersebut dimana karakter peduli sosial dicontohkan oleh Ucok pada konten ini (pengimplentasian dalam bentuk tersirat). Konten ini melatih ingat siswa dengan cara kuis melengkapi kotak disertai dengan foto yang berisi nama-nama tokoh dalam video tersebut (pengimplementasian dalam bentuk tersurat berupa tindakan).

Kerja keras merupakan karakter dasar yang harus dibangung sejak dini. Elfindri (2012: 102) menjelaskan bahwa karakter kerja keras adalah sifat seorang yang tidak mudah berputus asa yang disertai kemauan keras dalam berusaha dalam mencapai tujuan dan cita-citanya.guru membangun nilai karakter kerja keras seperti yang terdapat dalam konten ini dan mengilustrasikan dalam kehidupan nyata di masyarakat bahwa untuk menjadi pribadi sukses dan bermatabat kuncinya tidak mudah menyerah, selalu berusaha, dan bekerja keras.

8. Konten Keluarga Istimewaku

Konten berisi cerita yang luar biasa yaitu cerita "Aku dan Keluarga Istimewaku” Karya Enggar Ajar Adirasa. Terdapat beberapa nilai pendidikan karakter pada konten ini yaitu Nilai Karakter Peduli lingkungan, kreatif dan kerja keras. Peneliti lebih terfokus pada dua nilai karakter yang dominan dalam cerita tersebut, walaupun pada hakikatnya ketika kita kaji dengan analisis karya sastra tentu cerita tersebut memiliki nilai yang begitu kompleks.

"Pak Cahya setiap pagi berjalan mengelilingi kampung, pak Cahya mengumpulkan benda tidak terpakai seperti kaleng, botol, potongan kayu atau ranting. Benda-benda bekas tersebut dibawa Pak Cahya ke bengkel kecil disamping rumah. Benda benda tersebut kemudian Pak cahya ubah. Terkadang dia ubah menjadi rak bambu, talenan, dan pot bunga”. Cuplikan cerita Aku dan Keluarga Istimewaku tersebut nampak jelas menggambarkan tentang nilai karakter peduli lingkungan dan karakter kreatif yang dibuktikan oleh Pak Cahya dengan cara mengambil benda-benda bekas lalu 
Kukuh, Rian, Bagus. Empat Kata Judul Dari Depan...

di ubah menjadi barang berguna. Kegiatan pak cahya membutuhkan tenaga yang kita masukkan dalam karakter kerja keras.

Karakter peduli lingkungan yang terdapat dalam ilustrasi cerita pada game edukasi ini diharapakan dapat membangun kepedulian terhadap lingkungan sekitar, mencintai alam dan menjaga kebersihan. Sebagaimana yang dilakukan oleh pak cahya bahwa barang-barang bbekas masih sangat berguna jika dimanfaatkan dengan menggunakan kreatifitas. Buktinya bahwa kreatifitas Pak Cahya dalam mengolah barang-barang bekas menjadi kerajinan dan berguna bahkan dapat menjadi peluang usaha. Guru berharap siswa dapat terinspirasi dari cerita pak cahya sehinga mereka mencintai lingkungan dan kreatif. Selain peduli lingkungan dan kreatif dalam cuplikan ilustrasi cerita pada game edukasi Icando ini juga mengajak siswa untuk memiliki semangat kerja keras.

9. Konten menghitung perkakas

Sebagaimana kita pahami bersama, sub-tema pada tema diriku dalam game edukasi Icando tersebut disusun secara sistematis dengan pola pendekatan pribadi dimana diurut dengan hal yang berkenaan langsung dengan diri siswa itu sendiri, adapun konten ke sembilan ini tergolong lebih jauh karena sudah berada pada keluarganya dan tidak bersentuhan dengan dirinya yaitu pekakas rumah.

Sama halnya dengan beberapa konten sebelumnya, konten pada game ini disajikan dengan video terlebih dahulu. Kegiatan Alina membantu ayahnya untuk merapikan perkakas yang ada pada ilustrasi game tersebut menunjukkan nilai karakter peduli sosial yang coba ditunjukkan. Diakhir konten isi ada kuis menghitung jumlah perkakas yang merupakan implemetasi karakter kerja keras dan mandiri. Dapat disimpulkan, ada tiga nilai karakter yang diimplementasikan dalam konten ini yaitu Peduli sosial, Kerja keras dan Mandiri.

Nilai karakter peduli sosial, kerja keras dan mandiri terintegrasi pada konten ini. Proses penguatan karakter peduli sosial di konsep pada ilustrasi alina membantu ayahnya. Dengan konten ini siswa diharapkan dapat memiliki karakter suka membantu orang lain, dan tidak mudag putus asa. Selain itu siswa akan mampu menyelesaikan tanggung jawabnya secara mandiri. Nasution (2018:17) Kemandirian (Self reliance) merupakan kemampuan untuk mengelola semua yang dimilikinya sendiri yaitu 
Kukuh, Rian, Bagus. Empat Kata Judul Dari Depan...

mengetahui bagaimana mengelola waktu, berjalan dan berpikir secara mandiri disertai dengan kemampuan dalam mengambil keputusan dan memecahkan masalah

\section{B. Tubuhku}

Sama halnya dengan sub-tema sebelumnya, bagian ini juga bersentuhan langsung dengan kehidupan siswa yaitu "tubuhku". Hal ini tentu mendorong maksimalisasi pemahaman siswa terhadap hal yang hendak disampaikan. Ada beberapa konten yang ada pada sub-tema "tubuhku" yang dikemas dengan dengan menarik dan penuh kreatifitas. konten-konten yang dimaksud adalah membuka koper, bumbu dapur, bubu dan ikan tangkapan ayah, melindungi diri dan Anggota tubuh dan wajahku.

Masing-masing konten memiliki nilai karakter tersendiri sebagaimana bahasan berikut :

1. Konten membuka koper

Tanyangan video pada game edukasi Icando ini menunjukkan Ibu Alina bersikap santun kepada setiap orang dengan bertegur sapa, dan bersikap santun kepada penjual gelang dengan mengucapkan kata maaf ketika tidak membeli gelang. Dari sikap yang ditunjukkan dari ilustrasi video tersebut jelas menunjukkan karakter santun kepada orang lain yang tidak lain adalah bagian dari nilai karakter. Sopan santun adalah suatu tingkah laku yang amat populer dan ninali yang natural. Sopon santuan yang dimaksud adalah tingkah laku individu yang menghormati serta ramah terhadap orang yang sedang berinteraksi dengannya ( Djuwita, 2012:28). Konten pertama pada sub-tema "tubuhku" ini di akhiri dengan petunjuk kombinasi bilangan pada kode kunci koper.

2. Bumbu dapur

Nilai karakter pada konten bumbu dapur adalah pantang menyerah. Ilustrasi cerita ditunjukkan dengan dengan "Pertahanan diri dari serangan kelabang, meskipun kelabang menyerang Arya dengan jumlah yang banyak, siswa melindungi Arya dari serangan kelabang". Ulasan tersebut jelas menunjukkan adanya nilai pantang menyerah yang coba diimplementasikan dalam konten ini; hanya saja dengan bentuk yang unik yaitu permainan.

3. Bubu dan Ikan Tangkapan Ayah

Sama halnya dengan konsep sebelumnya, game ini dideskripsikan dengan video terlebih dahulu untuk disimak sebelum kemudian siswa dapat bermain dengan intruksi 
Kukuh, Rian, Bagus. Empat Kata Judul Dari Depan...

yang diberikan pada game edukasi Icando tersbut. Ada beberapa nilai karakter yang coba ditanamkan pada konten ke tiga ini.

Pertama nilai karakter Percaya diri dengan ilustrasi Para pembeli mulai berdatangan, Bubu menawarkan ikan dengan gencar. Siswa di dorong untuk memiliki rasa percaya diri yang tinggi sperti yang dicontohkan oleh Bubu saat menawarkan ikan dengan gencar, Bubu sangat memiliki rasa percaya diri yang tinggi dan tidak sedikitpun malu dalam menawarkan ikan.

Kedua Nilai karakter Peduli Sosial, pada konten ini Bubu mengobati kaki pria yang bercerita pengalaman saat berlayar. Karakter peduli sosial Bubu adalah membantu orang lain, ini sejalan dengan statemen Anas (2013:112) peduli sosial adalah sikap dan tindakan yang selalu ingin memberi bantuan pada orang lain dan masyarakat yang membutuhkan.

Ketiga merupakan nilai karakter Pantang menyerah pada ilustrasi Bubu berteriak dan mendorong pria jahat. Semangat pantang menyerah dalam kondisi sulit ditunjukkan oleh Bubu saat menghadapi pria jahat. Berusaha sekuat tenaga agar bias lepas dari cengkaraman pria jahat adalah bentuk nilai karakter pantang menyerah dan tidak mudah putus asa. Guru memberikan gambaran kepada siswa bahwa selama ada peluang untuk dapat menyelesaikan dapat melawan maka harus berusaha sampai tujuan yang diinginkan tercapai.

Menghargai prestasi adalah nilai karakter keempat yang muncul pada konten ini. Ilustrasinya Ibu dan Bubu mengucapkan terima kasih kepada paman. Bentuk penghargaan kepada orang lain oleh Ibu dan Bubu yang ditunjukkan kepada paman. Siswa diajak untuk membiasakan mengucapkan terima kasih kepada orang lain, apalagi jika orang lain telah membantu dalam proses interaksi sehari-hari.

4. Melindungi diri

Konten melindungi diri juga memiliki implementasi nilai karakter yang cukup banyak sehingga dapat dipastikan dapat menopang pembelajaran siswa secara utuh. Nilai karakter yang dimaksud sebagaiamana penjabaran berikut dengan ilustrasi pada kegaitan yang ada pada game tersebut.

Pertama, nilai karakter bersahabat ditunjukkan oleh Alina ketika bersosialisasi dan mengajak teman-temannya bermain bersama. Siswa mengamati dan diminta oleh guru untuk tetap menjaga persabahatan dan kebersamaan dalam pergaulan sehari-hari. 
Kukuh, Rian, Bagus. Empat Kata Judul Dari Depan...

Kedua, nilai karakter pantang menyerah, terlihat pada adegan ketika melawan orang asing, maka langkah pertama harus berteriak dengan sangat kecang, setalah itu lari dengan cepat sampai bertemu dengan orang tua dan menceritakan kepada orang tua. Guru memberikan penguatan karakter ini pada siswa dengan memberikan motivasi kepada siswa agar tidak mudah menyerah dan tidak putus asa.

5. Anggota tubuh dan wajahku

Konten ke-lima pada sub tema "tubuhku" dalam game tersebut lebih menekankan pada tindakan yang mengarah pada peningkatan kratifitas. Hal ini tentu bagian dari nilai karakter yang coba ditanamkan. Pengimplementasian nilai kreatif yang dimaksud adalah dengan intruksi memasangkang bagian organ tubuh yang dibuat terpisah pada gambar sesuai dengan tempatnya. Kreatif adalah sebuah kinerja. Kinerja dalam mewujudkan ide dan gagasan melalui serangkaian kegiatan intensif untuk menghasilkan sebuah karya cipta. Karya cipta yang berupa gagasan, kegiatan, karya artefak, sampai performa yang memiliki keunikan khusus yang menarik minat banyak orang (Kuniawan :2013) Siswa dipacu oleh guru dalam mengembangkan kraetifitas yang dimilikinya, serta terus berkarya mengembangkan bakat dan minat.

\section{SIMPULAN}

Berdasarkan hasil dan pembahasan maka penggunaan aplikasi game edukasi Icando pada sekolah dasar dapat memberikan kontribusi penguatan nilai-nilai pendidikan karakter diantaranya nilai karakter percaya diri, hormat dan santun kepada orang tua, tanggung jawab, rasa ingin tahu, menghargi prestasi, peduli sosial, peduli lingkungan, kreatif, dan pantang menyerah. Hal ini dapat disimpulkan bahwa game edukasi Icando sangat cocok dalam menopang penanaman nilai karakter kepada siswa sekolah dasar.

\section{UCAPAN TERIMA KASIH}

Bagian ini berisi ucapan terima kasih kepada sponsor, pendonor dana, narasumber, atau pihak-pihak yang berperan penting dalam pelaksanaan penelitian. 
Kukuh, Rian, Bagus. Empat Kata Judul Dari Depan...

\section{DAFTAR RUJUKAN}

Abdullah Yusuf Muhammad. (2015). Lego (Puzzle Bingo) Games: Media Edukatif Berbasis Pendidikan Karakter Pada Anak Usia Sekolah Dasar dalam Mewujudkan Generasi Indonesia Emas. Jurnal PENA. Volume 2(1)

Anas, S., dkk. (2013). Pendidikan Karakter (Pendidikan Berbasisi Agama dan Budaya Bangsa. Bandung: Pustaka Setia.

Antoro. Dwi Sunu. (2010). Pembudayaan Sikap Sopan Santun di Rumah dan Di Sekolah. Jurnal Pendidikan. Yogyakarta: Universitas Terbuka.

Apriono, D. (2011). Meningkatkan Keterampilan Kerjasama Siswa Dalam Belajar Melalui Pembelajaran Kolaboratif. Jurnal Prospektus,IX(2).

Astuti, N. P. E. (2020). Permainan tradisional Kancing Gumi dalam tinjauan pendidikan karakter (Studi kualitatif pada siswa SDN 1 Buahan, Tabanan Bali). Premiere Educandum : Jurnal Pendidikan Dasar dan Pembelajaran, 10(1), 63 71. Doi.org/10.25273/pe.v10i1.6162

Djuwita, Puspa. (2017). Pembinaan Etika Sopan Santun Peserta Didik Kelas V melalui Pembelajaran Pendidikan Kewarganegaraan di Sekolah Dasar Nomor 45 Kota Bengkulu. Jurnal Ilmiah Pendidikan Guru Sekolah Dasar, 10 (1)

Gyanprakash., Nagpal, K., James, L. (2013). Independent learning and student development. International journal of social science \& interdisciplinary research, 2 (2), 17-35

Elfindri, H. L., dkk. (2012). Pendidikan Karakter: Karakter, Metode dan Aplikasi untuk Pendidik dan Profesional. Jakarta: Baduose Media.

Gunawan, Heri. (2012). Pendidikan Karakter, Konsep dan Implementasi. Bandung: Alfabeta

Kusmarwanti. (2012). Menumbuhkan Karakter Anak Melalui Pemebelajaran Sastra di Sekolah Dasar. Makalah disampaikan dalam Seminar Nasional danTemu Alumni Dies Natalis ke-48 UNY.

Khotimah. (2019). Implementasi Program Penguatan Pendidikan Karakter (PPK) Melalui Kegiatan 5s Di Sekolah Dasar: Inopendas Jurnal Ilmiah Kependidikan 5443 Vol. 2 No. 1

Khoiri, Qolbi. (2018). Dimensions of Islamic Education in the Prevention Bullying; Assessing in an Effort of Character Building for Children in School. Jurnal Publikasi Pendidikan, 8(2), 101-108.

Kementerian Pendidikan Nasional.( 2010). Pengembangan Pendidikan Budaya dan Karakter Bangsa. Jakarta: Badan Penelitian dan Pengembangan Pusat Kurikulum.

Kurniawan, Syamsul. (2013). Pendidikan Karakter. Yogyakarta: Ar-Ruzz Media

Moleong, Lexy J. (2009). Metodologi Penelitian Kualiattif. Bandung: PT Remaja Rosdakarya

Nasution. (2018). Building Student Independence Through Character Education) Jurnal Ijtimaiyah Vol.2 No.1 Januari-Juni 2018 ISSN 2541-660X 
Kukuh, Rian, Bagus. Empat Kata Judul Dari Depan...

Ridwan, M. (2016). Ajaran Moral dan Karakter Dalam Fabel Kisah Dari Negeri Dongeng Karya Mulasih Tary. Premiere Educandum: Jurnal Pendidikan Dasar dan Pembelajaran. 6 (2) 95 - 109.

Sugiyono. (2010). Metode Penelitian Pendidikan Pendekatan Kuantitatif, Kualitatif, dan R\&D. Bandung: Alfabeta

Ulber, Silalahi. (2009). Metode Penelitian Sosial. Bandung: PT. Refika Aditama

Zuchdi, D. (2011). Pendidikan Karakter dalam Prespektif Teori dan Praktek. Yogyakarta: UNY Press. 